\title{
TRANSFORMING MORAL EDUCATION THROUGH BARAZANJI ACCULTURATION IN SOCIETY BUGIS MAKASSAR
}

\author{
By \\ Muhammadong ${ }^{1}$, Khaerunnisa ${ }^{2}$ \\ ${ }_{1,2}$ University of Makassar, Indonesia \\ Email: ${ }^{1}$ muhammadong@unm.ac.id, ${ }^{2}$ khaerunnisa@unm.ac.id
}

\begin{abstract}
Article Info
Articlehistory:

Received Nov 11, 2021

Revised Dec 25, 2021

Accepted Jan 19, 2022

\section{Keywords:}

Education, Barazanji reading,

Bugis Makassar community

ABSTRACT

The purpose of this research is find moral education in barazanji reading which can be transformed in the behavior of the Bugis Makassar community. This type of research is qualitative with a literature review method and is supported by primary data sourced from books by Sheikh Jakfar Albarazanji while secondary data is taken from interviews with religious leaders and community leaders. The results showed that the Bugis Makassar community was very inspired by reading barazanji because it contained an attitude of obedience, honesty, and mutual respect, so that they could be role models in their lives. In various celebrations, the reading of barazanji becomes the main reference because it contains praises, prayers, and prayers that can be transformed into moral education according to the current context so that there will be a revolution of views. Reading barazanji has become acculturation because it is in line with Islamic teachings so that people's enthusiasm is very high to develop their culture because it does not contradict their belief in strengthening their belief. The enthusiasm for developing barazanji is based on the compatibility between local cultures and religious fanaticism in South Sulawesi so that the community can be united.
\end{abstract}

Thisisan open accessarticleunderthe CC BY-SAlicense.

\author{
CorrespondingAuthor: \\ Muhammadong \\ University of Makassar, Indonesia, \\ Email: muhammadong@unm.ac.id
}

\section{INTRODUCTION}

Al-Qur'an and Hadisth are guidelines in human life so that they can achieve happiness and avoid difficulties. The existence of these two books is a reference for Muslims in living their lives so that they can be happy and avoid difficulties. It's just that the textualization of verses and hadiths is sometimes not found in solving religious problems that occur in the community so they seek ijtihadi efforts as an alternative problem solving. So it can be said that ijtihad is the third source in solving religious problems that occur in society related to religion. However, the step of ijtihadi can only be taken by remaining guided by the Qur'an and the Sunnah of the Prophet.(Sayyed Hossein Nasr: 2006)

The reality of people's lives in religion is sometimes faced with culture that must be lived without seeing the essence of religion. Religious messages are usually easier to understand through a cultural approach than the contextualization of verses and hadiths because the delivery of religion through culture is very easy to respond to because of its compatible nature that develops in society. (Mohammad Zuhri: 2012). Religion is a symbol that must be understood with various approaches, while culture is a method that is born from the community so that the level of acceptance of religion through culture is very easy to respond to because it has become a part of people's lives whose culture is very strict. Among the acculturation of society that is often used as a method of carrying out their religion is the reading of barazanji which has long developed and become the doctrine of the Bugis Makassar community.(Indra, H: 2016).

Reading the Barazanji book is a specification developed by NU residents in a religious event in order to maintain and preserve Islamic culture. These traditions are developed in each region with their respective styles 
without reducing the meaning contained in the reading of the book. (Schimmel Annemarie: 2013) The tradition of reading the book of Barazanji entered Indonesia because of the influence of the Persians in spreading Islam and the development of reading the book of Barazanji was growing rapidly along with the development of Islam in the archipelago. The interest of the students towards reading the book of Barazanji is very high because it can encourage them to practice their religion. So that reading the Barazanji book is easier to develop among Islamic boarding schools, especially on the island of Java and even on the mainland of Sulawesi. (Munawwar Abdul Fattah: 2012)

Barazanji is a book that contains prayers and praises as well as the history of the life of the Prophet Muhammad. The reading of the Baraznji book is only found at certain celebrations and celebrations such as aqiqah, brides, thanksgiving, birthdays, and other celebrations as a form of carrying out religious orders. Reading the book of barazanji is considered the sacredness of life so that it becomes a momentum in implementing Islamic teachings. Not a few among the Muslim community make barazanji reading as a symbol of unifying the people and cultural diversity and can also be a pattern in interpreting the teachings of the Prophet Muhammad. The position of reading the barazanji book is a priority because it can encourage Muslims to practice their religion so that not a few of them make it mandatory reading in various religious celebrations and activities. (Nasharuddin: 2015).

The book of barazanji is an idea that was initiated by a scholar from the village of Al-barazanji, namely Sheikh Ja'far Ibn Hasan Ibn Abdul Karim Ibn Muhammad Al-Barazanji. The ideas put forward in the book contain prose and poetry about the life journey of the Prophet Muhammad, which tells about his family, a small history, until the Prophet was appointed as an Apostle by Allah swt. And in the end, the book, tells about the example of the Prophet who can be used as an example in life and human life. (Muhammad Faisal, Rafiuddin Afkari, Sudanto: 2015).

Reading the book of Barazanji is a culture that is preserved by some Muslims because it is considered to have sacredness so that not a few make it the main guide in every religious activity and family celebration. Even some Muslims express the reading of the Barazanji book as an attitude of spiritualism and religious doctrine with various modes and behaviors. Among the prevailing doctrines is to be a deterrent from various damages and as a forum for gathering family members in a celebration. (Nasrul: 2015).

In South Sulawesi, the barazanji book has become a part of acculturation among them because it is considered as the main reading that must be realized in every activity or celebration. The Makassar Bugis people call mabbarazanji or abbarazanji for people who read the book of barazanji because it is read by several people alternately with different models and tones of voice. Reading the barazanji book has become a tradition that has been preserved among them until now in order to strengthen religious teachings that can reference the behavior of the Prophet Muhammad so that acculturation becomes a dynamically developing culture. (Stuart Hall,: 2006)

The Bugis Makassar community considers mabbarazanji or abbarazanji as a tradition that can strengthen their religious spirit because it is easy to develop and can be accepted by the community as a pillar of Islam. (Afriyantoni: 2015). Reading the book of barazanji is proof of the glue among them so that not a few use it as a mode to strengthen ties of kinship in family ties. For them mabbarazanji or abbarazanji is nothing but acculturation to prove love for the Prophet through cultural traditionalization so that Muslims canget closer to their religion. Reading the book of Baraznji for the Bugis Makassar community is a transformation that was developed through the tradition of reading the book I La Galigo which is easier to accept because it has a religious nuance.(Muttaqin, A: 2016)

In various celebrations, the Bugis Makassar community takes a role in developing their religion through the preservation of the mabbarazanji or abbarazanji culture. The reading of the barazanji book is nothing but the embodiment of religious values that want to be developed through religious acceleration through social activities so that Muslims can unite themselves within the framework of the state. The government's response to the reading of the barazanji book is very satisfying because the enthusiasm of Muslims is also very high. Reading the barazanji book seems to be a regional symbol in South Sulawesi to unite the Bugis Makassar community. This acculturation is intended to form a tradition embedded in religious activities. (Abudin Nata: 2013)

The implementation of barazanji can be carried out in various rituals related to the stages of their life cycle and can be carried out continuously. For example, if a member of the public enters a new house, then a barazanji reading is held, before the wedding, the mappacci ceremony is carried out first accompanied by the reading of the barazanji book. (Wulaningsih: 2014). The common thread that wants to be unraveled between religion and culture through acculturation of reading the barazanji book has always been a polemic among Muslims. Among them there are those who refuse on the grounds that it is not in accordance with the Sunnah of the Prophet and even deviates from Islamic teachings because the Prophet never exemplified it, but not a few of them preserve this culture on the grounds that in reading the book of Barazanji there are a number of Islamic teachings that teach love for the Prophet saw. (William C. Chittick: 2004)

The characteristics of the Bugis Makassar community in carrying out their religion are heavily influenced by culture and can even become a belief to justify an understanding so that understanding is actually neglected. 
International Journal of Social Science (IJSS)

Vol.1 Issue.5 February 2022, pp: 581-588

ISSN: 2798-3463 (Printed) | 2798-4079 (Online)

DOI: https://doi.org/10.53625/ijss.v1i5.1298

Cultural values that enter South Sulawesi are always integrated into religion so that they become an inseparable part. The meeting of cultural and religious currents takes a central position in shaping religious patterns. The linking of the two symbols aims to create religious universality through the long-rooted barazanji method in order to find common ground between cultural acculturation without violating the value of religious spiritualism.(Djazuli, A: 2017)

Barazanji acculturation has become a doctrine for the Bugis Makassar community in determining religious institutions. This culture has become part of their lives to determine the direction of Islam. The activity of reading the book of barazanji in various events is always shown to measure the quality of religion. Not a few of them present in a massive way because they consider it part of the faith that must be implemented in their lives. (Zubaidi: 2015). The Bugis Makassar community is willing to sacrifice materially as long as the barazanji activity can be carried out because it has become a culture that can be applied to their religious life. Religious institutions in South Sulawesi are not only seen in individual spiritual aspects, but the main benchmark focuses on social spirituality which is presented in the form of barazanji readings. Barazanji acculturation is an assessment factor to justify the advantages and glory of a society because it can display the religious side which includes prayer readings so that the Bugis Makassar are encouraged to develop it.(Ahmad Mujahid Abdullah: 2015).

The book of barazanji which is often read in various celebrations contains educational value that can lead to changes in the attitudes and mentality of the Bugis Makassar community. The reading of barazanji that is always chanted can lead to a better religious attitude because it can be accepted by all parties. The educational orientation initiated by the government is always supported by local culture through acculturation of barazanji which is religious because it teaches moral values in it. That is why Barazanji's reading has become a unifying culture in religious activities and the education system in South Sulawesi.(Abdullah A: 2016).

\section{METHODS}

This research is a field study with a qualitative descriptive approach. In this study, the researcher described the religious phenomenon of the Bugis Makassar community through reading the Barazanji book in South Sulawesi and then analyzed it using a normative sociological approach, phenomenology and Islamic studies. Sources of data used as references are primary and secondary data. (Lexy J Moelong: 2014). The primary data is the Bugis Makassar people who live in South Sulawesi. While secondary data is a reference related to Islamic studies. Data collection was carried out by interviewing and observing people reading the Barazanji book in various events. Then the documentation stage of each event is carried out, so that the data found in the field can be accounted for. The data found in the field were analyzed in order to draw conclusions. The technique used in analyzing can be taken through three stages, namely the reduction stage. At this stage, the data found in the field are simplified and grouped in order to produce accurate information about the religious behavior of the Bugis Makassar community.(Sugiono, 2017).

\section{RESULTS AND DISCUSSION \\ a. Results \\ 1. Bugis Makassar Ritualism}

The Bugis Makassar people are two tribes that inhabit the Sulawesi archipelago and parts of Kalimantan and Sumatra. They are very thick with their characters that are easy to maintain a culture that has been rooted for a long time so that it is difficult to change the character. The inclusion of syncretism became a motivator for them to develop religious rituals. The Bugis Makassar people are one of the various ethnic groups in Southeast Asia with a population of more than four million people, they belong to the Austronesian extended family. The life cycle ritual is a ceremonial activity that is difficult to forget among the Bugis Makassar which is closely related to the birth of a baby even though they cannot explain the meaning of the activity. But the most important thing for them is the spirit of the birth of a baby that can give good luck so that children need to be equipped with the spirit with the power of sumange as a symbol of the fundamental strength in the child.

The culture of the Bugis Makassar tribe in carrying out their wishes is very thick with rituals with various versions by adopting the culture of their ancestors before the entry of Islam. Glutinous rice and side dishes are the main menu in various celebrations with multiple variations so that their presence is highly awaited by the community in making offerings aimed at spirits. Servings are sometimes placed on a high place or ball attic so that the offering can elevate the degree. If the house does not have a ball attic, then the dish is kept on top of the cupboard so that it can ward off evil spirits.

During the offering process, frankincense is burned in order to attract the spirits of spirits. In the ritual process, the burning of incense is the main requirement so that the spirits of spirits do not disturb the family performing the ritual. In order to smell the festive atmosphere, incense is dripped with perfume then the guests are invited to taste the food in order to get a blessing so that the ritualism that is carried out becomes an encouragement 
in the life of the Bugis Makassar community. In the ritual process, guests perform blood anointing or live chicken ma'ccera and the blood is glued to the body so that evil spirits do not enter.

Along with the development of Islam in South Sulawesi, the rituals performed by the Makassar Bugis have shifted from the teachings of their ancestors to Islamic values. In various activities and celebrations, the nuances of Islam have always been an emphasis so that the activities carried out have religious values. As the month of Ramadan approaches, many residents perform assuro maca as a form of gratitude for being given a long life and reunited with the month of Ramadan. They sat cross-legged while waiting for the teacher to read prayers for the safety of the family. In the assuro maca activity, candles made of candlenut pallang are lit with the aim of avoiding various disturbances as well as asking for the safety of life.

The religious phenomenon of the Bugis Makassar tribe is very thick with a life of ritualism that must be celebrated through the reading of barazanji. The reading is proof of religious identity which is widely sacred in various activities, for example going on a pilgrimage, menre bola, oppeno lolo, assunna', abbotingen, having a new vehicle, having a new house, ammaulukeng. Many of them practice religious teachings based on the Syafi'i's mazhab so that they find leeway in carrying out their customs and are not as strict as other schools that can limit their culture. The Syafi'i's mazhab is very easy to accept because it is in line with ritualism that is often carried out. For them, reading barazanji has become a part of religious activities so that many of them are very sacred and celebrate it on a large scale at an expensive cost.

From some of the descriptions of the rituals described above, it appears that they overlap with each other when compared to Islamic rituals. However, the sacrifice of the animal is preceded by the word bismillah when it is about to slaughter. The dish that is served often includes a mountain of white sticky rice which is addressed to the prophet Muhammad. The prayers that are read before starting the thanksgiving ceremony are taken from Islamic teachings, and frankincense is also burned before people start reading a special book of verses from the Qur'an. In Bugis Makassar rites, sometimes it is preceded by reading the book of barzanji and reading thanksgiving prayers. However, the majority of the rites performed are not sourced from pure Islamic teachings, accompanied by the recitation of jampi-jampi.

\section{Barazanji Acculturation in South Sulawesi}

South Sulawesi is one of the provinces that is very thick with cultural preservation through the barazanji reading approach. This acculturation has been integrated into their lives in various events because it is considered part of Islamic teachings. To express religious spirituality, barazanji readings are always found in various events, such as aqiqah, birthday, marriage and other events, even on a large scale to give confidence that reading the book of barazanji is a form of contemplation in order to realize the teachings of the Rasulullah saw.

In an effort to revive Islamic law, the Bugis Makassar community treats Barazanji in the form of art and literature that can be competed so that it can attract the spirit of Muslims to develop their religion. The Bugis Makassar community considers Barazanji as a book that needs to be preserved because it contains the life journey of the Prophet Muhammad as a representation of Islamic teachings. Reading Barazanji means learning the nature and character of the Prophet which can be implemented in people's lives with the aim of being able to maintain the cycle of people's lives.

The Bugis Makassar community considers the reading of Barazanji not only as a medium for transferring spiritual values in shaping generations, but also as a fraternity that can unite their families. That is why, in every activity, barazanji readings are always served so that their family relationship is strengthened. It is still found among them that they are more concerned with traditional celebrations that include barazanji readings than their vertical worship to Allah swt. So it is not surprising that many of them do not pray, do not fast, but focus more on barazanji reading activities. They consider that the reading of barazanji and its various events has become part of worship that can bring them closer to Allah swt.

\section{Transformation of Moral Education in Barazanji.}

The Bugis Makassar community considers Barazanji not just reading that is served in various celebrations. The book of Barazanji contains in it the history of the life of the Prophet Muhammad which contains the education system. The paradigm of moral education can be found before the barazanji activity, namely being taught remembrance of Allah, mutual respect, upholding solidarity, so that it is imprinted in the souls of barazanji readers to practice religion well and prioritize the principle of tolerance. The reading of barazanji is always considered as a condition to start the celebration in order to get blessings and avoid danger so that its existence becomes mandatory and even considered imperfect a celebration if there is no barazanji reading.

Reading Barazanji is a symbol of Islam that can increase faith and love the Apostle more. This is in line with religious orders to always improve faith and draw closer to the Messenger of Allah. Society always considers barazanji an obligation that must be done to complete one's desires in life. Reading Barazanji is a transformation of religious teachings that must be implemented in actions so that it gives birth to noble character, good speech, 
International Journal of Social Science (IJSS)

Vol.1 Issue.5 February 2022, pp: 581-588

ISSN: 2798-3463 (Printed) | 2798-4079 (Online)

DOI: https://doi.org/10.53625/ijss.v1i5.1298

courtesy, honesty, and forgiveness. The realization of reading barazanji can give birth to obedience to Allah swt and an attitude of solidarity with fellow humans. Reading Barazanji seems to have merged with the spiritual joints of the Bugis Makassar community. So that every time there is a celebration activity, such as aqiqah, marriage, there is always an activity to read Barazanji.

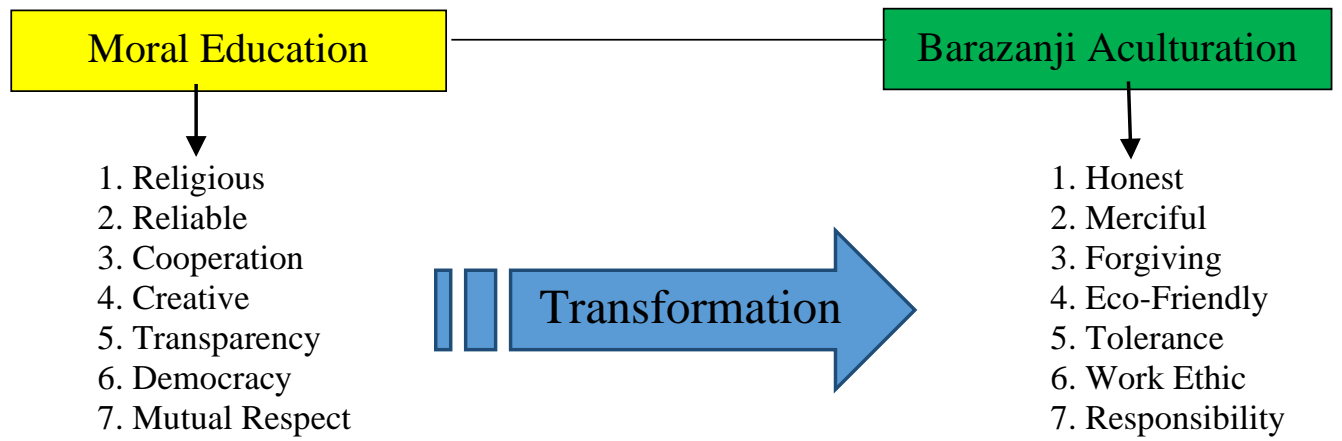

Table: Transformation of Moral Education in Barazanji Aculturation

The Bugis Makassar community always considers that barazanji activities are not just reading but are able to transform these activities into commendable behavior and far from disgraceful behavior. Their faith is getting stronger in carrying out their religion because it has become a part of the doctrines in their lives. In reading تركوا السفاح فلم يصبهم عاره من ادم والي أبيه و امه (they left adultery because the defects of adultery did not happen to them from Adam to their parents). The reading indicates that the act of adultery is highly reprehensible in Islamic teachings so it needs to be shunned. Maintaining chastity is part of their authority that needs to be maintained because it is very contrary to their customs. In South Sulawesi, adultery is immoral and is considered to bring disaster in a region. They assume that adultery always brings bad luck in their work so that whatever is done is always unprofitable. It's just that they are not anarchists in treating adulterers who must be judged in society.

The Bugis Makassar's people always exemplify greetings not only from the teachings of the Qur'an and hadith but also through reading barazanji as revealedويبدأ من لقيه بالسلام)(The Prophet always started greeting the people he met). They always socialize the greeting command in various ways, starting from the installation of greeting stickers that are affixed in certain places to the installation of banners that read an invitation to say hello. This proves the strong influence of barazanji activities because it has become a culture that is always preserved. They always assume that greetings are part of educational values so that people who say them always get awards.

\section{b. Discussion}

The Bugis Makassar' people are the dominant community in South Sulawesi and have spread to various provinces in Indonesia. The majority of them adhere to the Syafi'i ideology in carrying out their religious teachings and many adopt the teachings of Ahlusunnah wal Jama'ah. Not a few of them practice their religious teachings but are influenced by local culture. Bugis Makassar are two different tribes but they are united in culture and belief. Belief in gods cannot be denied because before the entry of Islam they believed in dynamism and animism as forms of culture. Islam as a religion that he believes in is very easy to accept because it can adapt to the culture adopted. Islam is not a religion that can be contested because it contains its universality.

The barazanji book is a reading that the Bugis Makassar Tribe is interested in in various activities because it contains religious elements that evoke their religious spirit. The barazanji reading is used as a guide because it can provide guidance to instill moral values so that the character of the reader can change in a positive direction. Even if not in a formal community, reading barazanji is part of non-formal education because it has its own community which is summarized in the pabbarazanji group in which it consists of religious leaders and community leaders who are involved in reading barazanji. These figures are always guiding and directing the community so that their views are in a better direction.

Moral education is a value that is integrated in an action whose content can apply universally. The urgency of moral education has become a part of human life so that its existence is needed. In order to realize a dignified life system, moral education is needed so that harmonization is realized in the midst of the development of the power of globalization and information. Moral education is needed to neutralize the development of civilization that leads to changes in values. In the Bugis Makassar society, moral education has become a doctrine capable of changing patterns in their lives. The level of influence is so strong on cultural values that its existence cannot be ignored. Culture becomes a priority scale in justifying civilization that is able to change people's behavior. 
Through the acculturation of Barazanji, people are increasingly motivated to practice their religion because it contains noble teachings. The historical values contained in it are able to transform their thoughts and behavior towards a more brilliant direction. That is why, the barazanji book is not just reading that is sung in prose but is able to indoctrinate them into behavior. In various religious and cultural activities, barazanji readings are always a priority to be presented because they consider that these activities are considered illegal if they are not accompanied by barazanji readings such as aqiqah activities, homecoming celebrations, weddings and others.

The urgency of reading barazanji is a community doctrine because it contains praises to the Prophet through the elements of shalawat it contains. The public's interest is very high in these activities, not only the religious elements that are raised but also related to the food menu served. The barazanji activity is carried out in groups without limiting the number of people and is carried out in turns with the order of reading and ending with prayers and prayers for the Prophet. What is even more interesting about the barazanji activity is that the readers of the barazanji receive gifts in the form of food and money, causing a feeling of joy.

The urgency of reading barazanji is a community doctrine because it contains praises to the Prophet through the elements of shalawat it contains. The public's interest is very high in these activities, not only the religious elements that are raised but also related to the food menu served. The barazanji activity is carried out in groups without limiting the number of people and is carried out in turns with the order of reading and ending with prayers and prayers for the Prophet. What is even more interesting about the barazanji activity is that the readers of the barazanji receive gifts in the form of food and money, causing a feeling of joy.

The moral values contained in barazanji really color people's lives because they are sourced from Islamic teachings that bring love to humans. The reference source for reading barazanji is certainly taken from the teachings of the Prophet Muhammad SAW who always teaches goodness and harmony in life. The enthusiasm of the people in reading barzanjji cannot be denied, not because of internal encouragement as a religious teaching that carries compassion but also because of external encouragement to preserve its culture. Reading barazanji has become acculturation because people consider it an integrated part between religious life and social life.

Barazanji acculturation can be transformed into moral education because its teachings are easily understood and accepted by all groups, especially when the community strongly adheres to the culture of both urban and rural communities because the culture applied is very religious in nature. The level of acceptance can be seen from the prose arrangement of barazanji sentences which can be conditioned to each culture. So that from one region to another, there is a lot of religion in reading barazanji but it does not reduce the goal to be achieved, namely developing Islamic teachings. Many people do not understand the reading but the religious spirit is very high because of the awareness to practice religion because acculturation has been integrated in their lives. The meeting of local culture with barazanji activities cannot be separated because what is highlighted is not just reading but Islamic symbols.

\section{CONCLUSION}

The urgency of moral education is to change behavior in a positive direction so that educational transformation occurs in both formal and non-formal institutions. Barazanji acculturation is a non-formal institution that is phenomenologically cultivated by the Bugis Makassar community because in it there are religious values that inspire character development. The barazanji book is not just reading but it contains the teachings of the Prophet's blessings so that people make references in every celebration. The moral education contained in it teaches morals to Allah swt and morals to fellow humans so that they can be used as examples in life. The existence of mabbarazanji continues to be preserved because the acculturation has received attention in the community. The enthusiasm for reading barazanji can inspire them to practice religion because it contains praise and prayers.

\section{REFERENCE}

[1] Abdullah, Ahmad Mujahid (2015) The Partice of Barazanji, Is in Line with Islamic Teaching; International Journal of West Asian Studies. Vol 4.

[2] Abdullah, A (2016) Islamization of South Sulawesi in Historical Perspective. Paramita: Historical Jounal 26(1), h. 88 .

[3] Annemarie, Schimmel (2013) Mystical Dimension of Islam. Jakarta: Mizan.

[4] Afriyantoni. (2015) Principles of Moral Education for the Young Generation. Yogyakarta: Deepublish

[5] Chittick, William C. (2004) On the Cosmology of Dhikir. Within Paths to the heart: Sufism and the Christian East (Edt. James S. Cutsinger. Indian: World Wisdom. H. 52.

[6] Djazuli, A (2016) The Rules of Fiqh: The Rules of Islamic Law in Solving Practical Problems. Cet. I; Jakarta: Prenada Media Gruf. 
International Journal of Social Science (IJSS)

Vol.1 Issue.5 February 2022, pp: 581-588

ISSN: 2798-3463 (Printed) | 2798-4079 (Online)

crossref DOI: https://doi.org/10.53625/ijjss.v1i5.1298

[7] Faisal, Muhammad, Rafiuddin Afkari, Sudanto (2015) Transformation of Sufi Teachings in the Malay Literature Sufism: Effor to Strengthening the Character Education Based on Local Wisdom in Kepulauan Riau. Proceedings of the 1 st International Conference on Character education. H. 4

[8] Fattah, Munawwar Abdul (2012) NU People Tradition. Yogyakarta: Pustaka Pesantren.

[9] Hall, Stuart (2006) Cultural Studies: An Introduction. London: Routledge

[10] Indra, H (2016) Islamic Education and Opportunities in the Era of Globalization. Yogyakarta: Deepublish.

[11] Moelong,J. Lexy (2014) Islamic Education and Opportunities in the Era of Globalization. Bandung: PT. Remaja Rosda karya.

[12] Muttaqin, A (2016) Barzanji Bugis in Commemoration of Maulid: Study of Living Hadith in the Bugis Society of Soppeng, South Sulawesi. Jurnal Living Hadis, 1, (1), h . 131.

[13] Nasr, Sayyed Hossein (2006) Islamic Philosophy from its Origin to the Present: Philosophy in the Land of Prophecy. Suny Series in Islam. Albany: State University of New York Press.

[14] Nasharuddin (2015) The Characteristics of a Perfect Human. Jakarta: Raja grafindo Persada.

[15] Nasrul (2015) Morals and Sufism. Yogyakarta: Aswaja Presindo.

[16] Nata, Abudin (2013) Capita Selecta Islamic Education. Jakarta: Raja Grafindo Persada.

[17] Sugiono (2017) Educational Methodology Quantitative Approach, Qualitative, $R \& D$. Bandung: Alfabeta.

[18] Sholikhin, Muhammad. (2011) Javanese Islamic Rituals and Traditions. Yogyakarta: Narasi.

[19] Wulaningsih (2014) The Role of the Assalafiyyah Islamic Boarding School in shaping the Character of the Santri in the Mlangi Tourism Village. Yogyakarta: UIN Sunan Kalijaga.

[20]Zubaidi (2015) Morals and Sufism. Yogyakarta: Lingkar Media.

[21]Zuhri, Mohammad (2012) Almaulidu Nabawi. Translation of Albarazanji. Semarang: Karya Toha Putra. 
THIS PAGE HAS INTENTIONALLY BEEN LEFT BLANK 